$5-1-2021$

\title{
Federalism, Democracy, and the 2020 Election
}

Hannah Jacobs Wiseman

Penn State Law

Samuel Wiseman

Penn State Law

David Landau

Florida State University College of Law

Follow this and additional works at: https://elibrary.law.psu.edu/fac_works

\section{Recommended Citation}

Hannah Jacobs Wiseman, Samuel Wiseman, and David Landau, Federalism, Democracy, and the 2020 Election, 99 Tex. L. Rev. (Online) 96 (2021).

This Article is brought to you for free and open access by the Faculty Works at Penn State Law eLibrary. It has been accepted for inclusion in Journal Articles by an authorized administrator of Penn State Law eLibrary. For more information, please contact ram6023@psu.edu. 


\title{
Texas Law Review Online
}

Volume 99

\section{Article}

\section{Federalism, Democracy, and the 2020 Election}

\author{
David Landau, Hannah J. Wiseman, and Samuel Wiseman ${ }^{\dagger}$
}

\begin{abstract}
In the aftermath of the 2020 election the United States experienced an antidemocratic crisis, with a chief executive attempting to delegitimize the general election and declare victory in an election that all impartial observers stated he lost. In comparative terms, the U.S. election system has been much maligned - it is highly localized and partisan, and lacks independent apex institutions, such as electoral tribunals, that are characteristic of many modern democracies. This brief essay builds off our recent joint work on federalism to argue that state and local governments, which administer elections and have refuted claims of widespread voter fraud, are serving as important bulwarks against this threat. By separating and dispersing the functions of governance - the day-to-day work of governing-U.S. federalism provides some protection against authoritarianism. The decentralization of authority over elections offers one particularly dramatic example of this dynamic in action. Indeed, the U.S. model of dispersing core functions, although messy and costly in other ways, may have advantages in some contexts over the alternative model of centralized apex institutions, especially by reducing vulnerability to capture.
\end{abstract}

$\dagger$ Mason Ladd Professor and Associate Dean for International Programs, Florida State University College of Law, A.B., J.D., and Ph.D. (Political Science) Harvard University; Professor of Law, Penn State Law-University Park, A.B., Dartmouth College, J.D., Yale Law School; Professor of Law, Penn State Law-University Park; B.A. and J.D., Yale University. 


\section{Introduction}

The United States recently experienced an antidemocratic crisis, with a President attempting to delegitimize the general election and unilaterally declare victory in an election that all impartial observers stated he lost. ${ }^{1}$ Starting well before the election, then-President Trump initiated a widespread public relations campaign to persuade the American public that the election would be infected with fraud - part of an apparently premeditated plan to declare victory on election night regardless of actual results. ${ }^{2}$ After losing the election, and without citing any credible evidence, he declared that widespread corruption and fraud had occurred. ${ }^{3}$ The President attempted to block the counting of thousands of legitimate votes through the courts and other outlets, demanding on social media that counties "STOP THE COUNT," and fanning the flames of violent protests at county election offices. ${ }^{4} \mathrm{He}$ refused to

1. In televised statements from the White House, from which news networks quickly pulled away due to a lack of fact-checking, then-President Trump asserted on November 5: "We were winning in all the key locations by a lot, actually. And then our number started miraculously getting whittled away in secret, and they wouldn't allow legally permissible observers." President Donald Trump, Remarks by President Trump on the Election (Nov. 5, 2020), https://trumpwhitehouse.archives.gov/briefings-statements/remarks-president-trump-election/ [https:/perma.cc/9JSQ-CS38]. On Twitter, President Trump stated, "Last night I was leading, often solidly, in many key States, in almost all instances Democrat run \& controlled. Then, one by one, they started to magically disappear as surprise ballot dumps were counted. VERY STRANGE." Twitter later flagged and removed the posts as potentially misleading. U.S. Election: Twitter Hides Trump Tweet about 'Disappearing' Lead, BBC NEwS (Nov. 4, 2020), https://www.bbc.com/news/technology-54809165 [https://perma.cc/6PDQ-7TL8]. President Trump's appointees exacerbated these authoritarian efforts. For example, Attorney General William Barr authorized all federal prosecutors to "investigate 'specific allegations' of voter fraud before the results of the presidential race are certified ... Mr. Barr's directive ignored the Justice Department's longstanding policies intended to keep law enforcement from affecting the outcome of an election." Katie Benner \& Michael S. Schmidt, Barr Hands Prosecutors the Authority to Investigate Voter Fraud Claims, N.Y. TIMES (Nov. 9, 2020), https://www.nytimes.com/2020/11/09/us/politics/barr-elections.html [https://perma.cc/ESH9TYWS].

2. See Jonathan Swan \& Zachary Basu, Off the Rails Episode 1: A Premeditated Lie Lit the Fire, AxIOS (Jan. 16, 2021), https://www.axios.com/trump-election-premeditated-lie-ebaf4a1f-46bf4c37-ba0d-3ed5536ef537.html [https://perma.cc/66RB-UP5L].

3. See Marianna Spring, 'Stop the Steal': The Deep Roots of Trump's 'Voter Fraud' Strategy, BBC (Nov. 23, 2020), https://www.bbc.com/news/blogs-trending-55009950 [https://perma.cc/F4W3-PWF4] (noting that "President Trump first started tweeting allegations of fraud as far back as April" and that "[b]etween then and the election, he mentioned rigged elections or voter fraud more than 70 times"); Trump, supra note 1 ("We'll not allow the corruption to steal such an important election or any election, for that matter. And we can't allow silence -anybody to silence our voters and manufacture results .... This was unprecedented in American history. This was by design.").

4. On November 5th, President Trump tweeted "STOP THE COUNT!" Libby Cathey, Trump Calls for Vote Counting to Stop as Path to Victory Narrows, Biden Urges All to 'Stay Calm', ABC NEWS (Nov. 5, 2020, 4:20 PM), https://abcnews.go.com/Politics/overview-trump-calls-vote-counting-stop-path-victory/story?id=74038071 [https://perma.cc/NT52-DVTK]. Later that evening, President Trump stated from the Press Briefing Room: 
concede the election, and for several weeks after the election his officials denied the President-elect access to intelligence briefings and other transition resources provided for by law. ${ }^{5}$

Further, President Trump and his lawyers tried to interfere with the electoral college process in key ways, filing lawsuits and pressuring state and local officials to alter or refuse to certify results. ${ }^{6}$ These efforts came to a head on January 6, 2021, when Trump riled up a violent mob to storm the United States Capitol in order to interfere with the certification and counting of electoral votes. ${ }^{7}$

The 2020 election process demonstrated that state and local governments, which administer elections and have refuted claims of widespread

If you count the legal votes, I easily win. If you count the illegal votes, they can try to steal the election from us. If you count the votes that came in late-we're looking at them very strongly. But a lot of votes came in late .... To the best of my knowledge, votes should be in by Election Day, and they didn't do that.

Trump, supra note 1. Meanwhile, protestors, some of them armed, stood outside vote-counting facilities, demanding votes either be counted or stop being counted, depending on whether Trump was leading in that county. Jemima McEvoy, 'Stop the Count': Protestors Surround Detroit Vote Counting Site After Trump Lawsuit, FORBES (Nov. 4, 2020, 4:43 PM), https:/www.forbes.com/sites/jemimamcevoy/2020/11/04/stop-the-count-protesters-surround-detroit-vote-counting-site-after-trumplawsuit/?sh=e8d85b64328b [https://perma.cc/6438-SK22] (describing protestors chanting "stop the count" in Michigan when Trump began losing his earlier lead to Biden); Simon Romero, Trump Supporters Protest at Maricopa County Vote-Counting Site, N.Y. TIMES (Nov. 5, 2020), https://www.nytimes.com/2020/11/04/us/politics/trump-supporters-protest-arizona.html [https://perma.cc/YQR7-CKUH] (describing protestors demanding officials count every vote where Trump was tailing Biden in Maricopa County).

5. Michael D. Shear, Maggie Haberman \& Michael Crowley, Trump Appointee Stands Between Biden's Team and a Smooth Transition, N.Y. TIMES (Nov. 9, 2020), https://www.nytimes.com/2020/11/09/us/politics/emily-murphy-trump-biden.html [https://perma.cc/EE5DNAPF] (noting how the leader of the General Service Administration denied President-Elect Biden's transition team access to agencies, offices, and funding typically reserved for the incoming president).

6. Maggie Haberman, Jim Rutenberg, Nick Corasanti \& Reid J. Epstein, Trump Targets Michigan in His Ploy to Subvert the Election, N.Y. TIMES (Nov. 19, 2020), https://www.nytimes.com /2020/11/19/us/politics/trump-michigan-election.html [https://perma.cc/FC2U-SGF6] (describing Trump's White House meeting with Michigan's top legislative officials and a phone call to a Wayne County election official before Michigan certified its election results); Heidi Przybyla, Dareh Gregorian \& Adam Edelman, After Meeting with Trump, Michigan Lawmakers Say They See Nothing to Overturn Biden's Win, NBC NEws (Nov. 20, 2020, 11:46 AM), https://www.nbcnews.com/politics/white-house/michigan-gop-lawmakers-heckled-arrival-white-house-meeting-n1248396 [https://perma.cc/X6Y2-HTVF] (quoting campaign lawyer Sidney Powell as stating, "The entire election, frankly, in all the swing states should be overturned, and the legislatures should make sure that the electors are selected for Trump"); infra note 82 and accompanying text (describing sixtytwo lawsuits).

7. See Washington Post Staff, Woman Dies After Shooting in U.S. Capitol; D.C. National Guard Activated After Mob Breaches Building, WASH. POST (Jan. 6, 2021, 11:52 PM), https://www.washingtonpost.com/dc-md-va/2021/01/06/dc-protests-trump-rally-live-updates/

[https://perma.cc/FC9M-Z8XJ] (describing the events of the riot). 
voter fraud, served as important (albeit highly imperfect) bulwarks against the threat of authoritarianism. If the federal government had more direct control over elections, the situation-perilous as it was - would likely have been far worse. By separating and dispersing the functions of governance- the day-to-day work of governing-U.S. federalism substantially curbs the power of a potentially autocratic executive. ${ }^{8}$ U.S. federalism thus served as an important protection of democracy in the aftermath of the 2020 presidential election and attempts to defy the election outcome.

The threat of erosion of American democracy follows a familiar pattern to that seen elsewhere. A number of countries around the world have experienced "democratic backsliding" over the past several decades. ${ }^{9}$ Recent collapses of democracy have tended to occur not via military coup, but instead via legal actions taken by duly elected leaders and their allies..$^{10}$ These leaders use a number of different mechanisms to entrench themselves in power and undermine the opposition-effectively tilting the electoral playing field heavily in their favor. ${ }^{11}$

During the leadership of the Trump administration, comparativists who have studied democratic collapses abroad have noted that the U.S. is vulnerable to this kind of backsliding. They have observed that the former President's rhetoric is similar to that of authoritarians abroad, and moreover, that the United States seems to lack the institutional protections (such as an independent electoral court or anticorruption body) that would protect democracy in the event of a threat. ${ }^{12}$ And in the wake of former President Trump's determined effort to refute the election, experts have described recent events as "one of the gravest threats to democracy," noting that they "never would have imagined seeing something like this in America."13

8. David Landau, Hannah J. Wiseman \& Samuel R. Wiseman, Federalism for the Worst Case, 105 IOWA L. REV. 1187, 1190 (2020).

9. Staffan I. Lindberg, The Nature of Democratic Backsliding in Europe, CARNEGIE EUROPE (July 24, 2018), https://carnegieeurope.eu/2018/07/24/nature-of-democratic-backsliding-in-europepub-76868 [https://perma.cc/YQ6U-7QRY].

10. Landau, Wiseman \& Wiseman, supra note 8, at 1197.

11. Steven LeVitsky \& Daniel Ziblatt, How Democracies Die 2, 21-24 (2018) (identifying four factors that make leaders authoritarian, including rejecting the traditional rules of the democratic game, denying political opponents' legitimacy, tolerating or encouraging violence, and being willing to "curtail the civil liberties of rivals and critics").

12. 'How Democracies Die' Authors Say Trump Is a Symptom of Deeper Problems, NPR (Jan. 22, 2018, 1:25 PM), https://www.npr.org/2018/01/22/579670528/how-democracies-die-authorssay-trump-is-a-symptom-of-deeper-problems [https://perma.cc/Z7TR-PHA5].

13. David Leonhardt, Trump's Refusal to Concede, N.Y. TIMES (Nov. 12, 2020) https://www.nytimes.com/2020/11/12/briefing/ron-klain-jeffrey-toobin-tropical-storm-eta.html [https://perma.cc/947B-YQZP] (quoting Ryan Enos, a Harvard social scientist, and Michael Abramowitz, president of Freedom House). 
Against a backdrop of a dangerous move toward authoritarianism in the United States, we demonstrated in an earlier article that the U.S. version of federalism - which decentralizes core functions of governance such as judging, law enforcement, and electoral administration — offered significant protection. ${ }^{14}$ Federalism for the Worst Case argued that the structural separation of governance duties between the federal government and the states is antiauthoritarian in a manner different from that envisioned by the Framers and other theorists. ${ }^{15}$ Specifically, states do not just serve as "guard dogs" for any federal misbehavior or as governments that compete with the federal government for voter affection. Instead, states remain significantly functionally independent of, and resistant to capture by, the Executive Branch due to a uniquely American mix of tradition, doctrine, and resource constraints. ${ }^{16}$ Due to the way that the administration of governance has evolved over time, states perform the day-to-day groundwork of governance in some of the most important areas of U.S. residents' lives. State and local governments administer elections, do the vast majority of criminal policing, and maintain independent courts that dictate the outcome of millions of civil and criminal disputes. ${ }^{17}$

Thus, in the case of threatened tyranny, U.S.-style federalism - in which local governments and states carry out numerous administrative aspects of governance - serves a protection function not replicated by any other aspect of our political structure. The separation of governing duties between the federal government and states helps to prevent the federal government from rapidly taking control and converting our democracy to an authoritarian regime. ${ }^{18}$

This Article builds upon our institutional theory of federalism as a bulwark against tyranny, highlighting the U.S. election crisis to show the essential nature of state and local actors in preventing tyranny. We do not argue here that states are perfect, uniformly well-intentioned, or even competent when it comes to governing in general and to elections in particular. The events of 2020 make that abundantly clear. ${ }^{19}$ But the case study of the election crisis supports the argument that U.S.-style federalism remains a safeguard against authoritarianism despite the many flaws of the system.

14. Landau, Wiseman \& Wiseman, supra note 8 , at 1190.

15. Id.

16. The Federalist No. 28 at 228-29 (Alexander Hamilton) (John C. Hamilton ed., 1864) (arguing that state legislatures would "discover the danger" of a federal government's potential invasions of public liberty); Note, Defending Federalism: Realizing Publius's Vision, 122 HARV. L. REV. 745, 746 (2008) (exploring the "guard dog" account).

17. Landau, Wiseman \& Wiseman, supra note 8 , at 1213, 1217-25.

18. See Murphy v. NCAA, 138 S. Ct. 1461, 1477 (2018) (describing how the anticomandeering doctrine reduces the risk of authoritarianism); Printz v. United States, 521 U.S. 898, 933 (1997) (same); New York v. United States, 505 U.S. 144, 187-88 (1992) (same).

19. See infra Part II for discussion of states' disenfranchisement of voters in the 2020 election. 
Part I further builds upon the theory propounded in Federalism for the Worst Case by outlining two ways in which a nation might protect democracy. The first route, more common in other constitutions around the world, is to centralize sensitive functions in the hands of independent apex institutions. The United States has largely eschewed this route in favor of dispersing core functions among the states, often in the hands of less insulated and more partisan actors. This second route is far messier but may sometimes reduce downside risks by making capture of government by the Executive more difficult and time-consuming.

Part II further digs into the role that the decentralization of election administration may have played in protecting the outcome of the 2020 election. Our argument is not that U.S. federalism makes an authoritarian takeover impossible. In fact, the 2020 election exposed some weak points through which future movements towards authoritarianism might succeed. On the whole, however, we do think that our federal system makes democratic decline less likely. Part III explores some significant costs of the U.S. model of federalism that the 2020 election illuminated, including localized tyranny, inefficiency, and blame-shifting. These costs demonstrate that U.S. federalism is unlikely to be a first-best solution. But by serving as a kind of insurance policy that makes worst-case scenarios less likely, it might be a reasonable (if imperfect) second best. As we conclude in Part IV, the decentralized U.S. model of electoral administration might be improved if it were also more insulated from partisan capture, thus combining the logic of the two models of democratic protection.

\section{Two Models of Democratic Protection: Insulated Centralization Versus Dispersion}

In Federalism for the Worst Case, we described two types of modern constitutional protections of democracy. By far the dominant model in constitutions around the world is to create apex-level institutions that are insulated from political pressure by the constitution itself, and which defend sensitive democratic functions. ${ }^{20}$ For example, many constitutions now require independent bodies such as anticorruption commissions (to handle prosecutions of high-level politicians where a self-dealing problem would otherwise exist), human rights commissions (to protect minority rights), and media commissions (to promote and protect an independent press) in addition to high courts or constitutional tribunals. ${ }^{21}$

Most strikingly, the vast majority of constitutions create independent electoral commissions or tribunals charged with running proficient elections

\footnotetext{
20. Landau, Wiseman \& Wiseman, supra note 8, at 1204.
}

21. Id. 
and preventing political interference or fraud with those events. ${ }^{22}$ In some countries, these tribunals have played a major role in protecting fragile democracies. For example, in Mexico, the independent Electoral Tribunal, created in 1994, has been credited with helping to shepherd the country from authoritarianism to democracy, and has consistently been praised for defending the integrity of Mexican elections. ${ }^{23}$

Insulating high-level institutions is a workable strategy in many contexts. Its most glaring weakness, however, is its amenability to capture. Authoritarian actors may be able to change the rules, game the rules, or just play a patient waiting game in order to place a majority of loyal allies on these institutions. Once captured, the institution might begin to attack democracy rather than defend it. This problem is illustrated by recent events in Poland, where the ruling Law and Justice Party has managed to capture both the Constitutional Court and the National Election Commission and has used them to cement itself in power. ${ }^{24}$ And in Venezuela, the National Electoral Council nullified the results of several elections favorable to the opposition and stopped a recall of a Maduro mandate, citing alleged fraud. ${ }^{25}$

In terms of the modern paradigm of independent democracy-protecting institutions, the United States looks dangerously vulnerable. Other than the Supreme Court, which now has a solid conservative majority following Justice Ginsburg's replacement by Justice Barrett, the country largely lacks the battery of national-level democracy-protecting institutions found elsewhere around the world. Consider the Mueller investigation, where the Justice Department official charged with investigating wrongdoing by President Trump and those around him were left uninsulated (even by statute); commentators speculated that the official could have accordingly been fired at any time. ${ }^{26}$

Perhaps the clearest example of the United States' distinctive approach to democracy protection is elections. There is no apex-level independent

22. Id.

23. Todd A. Eisenstadt, Courting Democracy In MeXico: Party Strategies AND ELECTORAL INSTITUTIONS 66-69, 253-54 (2004).

24. See Wojciech Sadurski, How Democracy Dies (in Poland): A Case Study of Anti-Constitutional Populist Backsliding 4-5 (Sydney Law Sch., Research Paper No. 18/01, 2018), https://papers.ssrn.com/sol3/papers.cfm?abstract_id=3103491 [https://perma.cc/EYE7-D3DC].

25. David Landau, Constitution-Making and Authoritarianism in Venezuela: The First Time as Tragedy, the Second as Farce, in CONSTITUTIONAL DEMOCRACY IN CRISIS? 161, 169-170 (Mark A. Graber et al. eds., 2018).

26. See, e.g., Jordain Carney, Mueller Protection Bill Blocked in Senate for Third Time, HILL (Dec. 19, 2018, 6:00 PM), https://thehill.com/homenews/senate/422171-mueller-protection-billblocked-in-senate-for-third-time [https://perma.cc/ZRH8-QFZT] (noting a failed bill that would have codified Justice Department regulations requiring the action of a senior department official to fire Mueller). 
electoral tribunal, and the main federal body charged with regulating elections, the Federal Elections Commission, has long been criticized as a relatively weak and indecisive body. ${ }^{27}$ The FEC lost quorum in July, and was unable to act until December, when new commissioners were seated. ${ }^{28} \mathrm{Re}$ gardless, there is little confidence in its ability to effectively enforce campaign finance laws. ${ }^{29}$ Instead, elections in the United States are administered in a strikingly decentralized fashion, controlled by states and counties with a welter of different rules for voting and counting votes. ${ }^{30}$ In some cases, these local boards are not especially insulated from politics, since key officials themselves may be subject to election. Many observers, both inside and

27. See, e.g., Samuel Issacharoff \& Pamela S. Karlan, The Hydraulics of Campaign Finance Reform, 77 TEXAS L. REV. 1705, 1712 (1999) (noting the unlikelihood that the FEC would regulate in a manner that would meaningfully reform campaign finance through regulation and enforcement and citing to the weakness of the agency).

28. Kate Ackley, FEC Set to Lose its Quorum Again, Roll CALl (June 26, 2020, 3:31 PM), https://www.rollcall.com/2020/06/26/fec-set-to-lose-its-quorum-again/ [https://perma.cc/JGB7JSL2] (noting a brief period in which the FEC had enough members to hold an official meeting and another resignation that once again caused the Commission to lack a quorum); Brian Naylor, The Federal Election Commission Can Finally Meet Again. And It Has a Big Backlog, NPR (Dec. 24, 2020, 5:00 AM), https://www.npr.org/2020/12/24/949672803/the-federal-election-commissioncan-finally-meet-again-and-it-has-a-big-backlog [https://perma.cc/9F2V-CVSD].

29. Naylor, supra note 28.

30. To take two stark examples, California allows voter registration at the polling place on Election Day and does not require most voters to show an ID when voting. CAL. ELEC. CODE $\S 2170(\mathrm{c})$ (West, Westlaw through Ch. 2 of 2021 Reg. Sess.) (allowing conditional voter registration on Election Day); What to Bring to Your Polling Place, CAL. SEC'Y OF STATE, https://www.sos.ca.gov /elections/voting-resources/voting-california/what-bring [https://perma.cc/MG7J-E4YL] ("In most cases, a California voter is not required to show identification to a polling place worker before casting a ballot."). Texas, by contrast, requires voter registration 30 days prior to Election Day and requires voters to provide a Texas driver's license, election ID certificate, Texas personal ID card, Texas handgun license, U.S. citizenship certificate, U.S. military ID card, or U.S. passport. TEX. ELEC. CODE § 13.143(a) (West, Westlaw through 2019 Reg. Sess.) (providing the voter registration deadline); Required Identification for Voting in Person, TEX. SEC'Y OF STATE, https:// www.votetexas.gov/register-to-vote/need-id.html [https://perma.cc/2S3E-CWSR]. Access to voting and vote-counting procedures were even more starkly divided during the pandemic. Some states automatically provided mail-in ballots to all voters and offered extensive drop boxes and return options, other states imposed strict procedural hurdles on mail-in ballot requests and ballot completions, and still others prohibited voters from requesting mail-in ballots on the basis of COVID-19 concerns. See, e.g., Elise Viebeck \& Arelis R. Hernández, Coronavirus Cases Are Surging Again. These States Have Refused to Loosen Rules on Who Can Vote By Mail., WASH. Post (Oct. 26, 2020, 5:02 PM), https:/www.washingtonpost.com/politics/vote-limits-coronavirus/2020/10/25 1523538c8-1223-11eb-ad6f-36c93e6e94fb_story.html [https://perma.cc/3KQM-6ERD] (noting a refusal to loosen mail-in voting rules in Texas, Indiana, Louisiana, Mississippi, and Tennessee); How to Vote in New Jersey, N.J. DeP'T OF STATE, Div. OF EleCtIONS, https://www.state.nj.us/state /elections/vote-how-to.shtml [https://perma.cc/H7B4-4Y6T] (noting that "[a]ll active registered voters in New Jersey will automatically receive their ballots in the mail"); Witness Signature Required for Mail-in Ballots, S.C. ELECTION COMM'N, https://www.scvotes.gov/witness-signaturerequired-mail-ballots [https://perma.cc/3WSP-254X] (requiring voters to have a witness sign their mail-in ballot for ballots received after October 7). 
outside the United States, looked on with concern after the 2020 election, struck by the haphazard nature of U.S. electoral administration. ${ }^{31}$

But the U.S. approach to federalism in fact represents an alternative model of protecting democracy: dispersing control of core functions, including the administration of elections, to the states. In Federalism for the Worst Case, we argued that U.S. federalism tends to significantly decentralize not only control of elections, but also other core functions such as judging, prosecuting, and policing. Thousands of local and state officials hear the majority of court cases; police the streets; and, as highlighted here, administer all aspects of elections, including the election of federal officials. ${ }^{32}$ The result is a process that is often messy, is sometimes inefficient, and can even be unprofessional. ${ }^{33}$ However, it also mitigates the major risk of the apex-level institution approach by making capture far less likely. Interestingly, then, the decentralized, messy nature of U.S. electoral administration may be a reasonably effective bulwark against efforts by an authoritarian president to make the overall electoral playing field unfair.

Our argument is not that all forms of federalism provide this protection, but rather that the United States' historically constructed variant of federalism does a reasonable job of doing so, despite its costs. The U.S. approach of dispersing control over key functions is fairly distinctive in comparative terms. Many countries around the world have federal systems, but nonetheless have quite centralized electoral administrators, judges, police forces, and prosecutors. ${ }^{34}$ And in some countries, chief executives can rely on emergency powers to easily establish control over state personnel. ${ }^{35}$

The U.S. version of federalism - with quite decentralized control over sensitive democratic functions - is a product of a broad mix of factors. In part, of course, it stems from the Constitution itself. The text, for example,

\footnotetext{
31. See, e.g., COVID-Related Election Litigation Tracker, STANFORD-MIT HEALTHY ELECTIONS PROJECT, https:/healthyelections-case-tracker.stanford.edu/search [https://perma.cc/2XEA-8R4V] (noting more than 500 cases challenging election procedures in forty-six states, plus D.C. and Puerto Rico); U.S. Election 2020: When Will We Know the Result?, BBC News (Nov. 4, 2020), https://www.bbc.com/news/election-us-2020-54096399 [https://perma.cc/N4VU-4R8R] (citing to the Stanford-MIT report and noting previous problems with state-administered elections, as in the 2000 election).

32. Landau, Wiseman \& Wiseman, supra note 8, at 1213, 1218, 1220-22.

33. Id. at $1192 \mathrm{n} .19$ (noting the inefficiencies of anticommandeering, in that it prevents state officials from enhancing certain powers by sharing enforcement responsibilities and other powers with the federal government).

34. See id. at 1198-1201,1211, 1216, 1218, 1220 (describing the centralized political apparatuses of other countries with federalist governments such as Mexico, Venezuela, and Russia).

35. See, e.g., Bhagwan D. Dua, Presidential Rule in India: A Study in Crisis Politics, 19 ASIAN SURV. 611, 611-12 (1979) (describing Indira Gandhi's use of emergency powers to dissolve state governments under opposition control).
} 
gives state legislatures broad powers to determine the time, place, and manner of even federal elections, although it also gives Congress the power to "make or alter" those regulations as it chooses. ${ }^{36}$ Commentators have noted that much of Congress's residual authority in this area has gone unused. ${ }^{37}$ But some Supreme Court doctrines may bolster the independence of state authorities. For example, the anticommandeering doctrine generally prevents the federal government from forcing state or local officials to enforce federal law. ${ }^{38}$

Although some U.S. decentralization is the product of the Constitution, much of it is a result of history and practice not directly compelled by either the Constitution or the Supreme Court. As already noted, Congress plausibly has much more authority under the Elections Clause than it has ever used. ${ }^{39}$ Using the Commerce Clause, Congress could also vastly expand the reach of federal criminal law, even though the bulk of criminal jurisdiction has always resided with the states. ${ }^{40}$ Finally, nothing apparent in the Constitution would stop the federal government from massively expanding the number of federal law enforcement personnel, who are currently far outnumbered by their state and local counterparts.

This type of sweeping expansion could lead to a significant erosion of the protective function we have identified. Consider the consternation caused this summer by the Trump administration's movement of federal law enforcement personnel to cities such as Portland, Oregon, during protests linked to the Black Lives Matter movement. ${ }^{41}$ This concern would be substantially heightened if the federal government, rather than state and local authorities, were the dominant law enforcement presence in the country.

The force that has prevented widespread federal takeover of these types of functions is probably not constitutional doctrine, but rather historical and practical factors. Citizens expect most law enforcement operations to be

36. U.S. CONST. art. I, $\S 4$, cl. 1 .

37. See, e.g., Samuel Issacharoff, Commentary, Beyond the Discrimination Model on Voting, 127 HARV. L. REV. 95, 112-13 (2013) (arguing that Congress could have stepped in to address a variety of recent U.S. voting issues); Justin Weinstein-Tull, Election Law Federalism, 114 MICH. L. REV. 747, 775 (2016).

38. See Printz v. United States, 521 U.S. 898, 935 (1997); New York v. United States, 505 U.S. 144, 188 (1992).

39. See Issacharoff, supra note 37 and accompanying text.

40. Thomas J. Maroney, Fifty Years of Federalization of Criminal Law: Sounding the Alarm or “Crying Wolf?", 50 SYRACUSE L. REV. 1317, 1326-29 (2000) (noting few checks on federal criminal law jurisdiction).

41. See, e.g., Giovanni Russonello, What Are Federal Agents Doing in Portland?, N.Y. TIMES (July 20, 2020), https://www.nytimes.com/2020/07/20/us/politics/portland-federal-agentstrump.html [https://perma.cc/EWW4-VQK2] (noting opposition by protesters, the state of Oregon, and municipal leadership to " $[\mathrm{m}] \mathrm{ilitary}$-clad agents reporting to the Department of Homeland Security" policing protests in Portland). 
local. ${ }^{42}$ And the amount of new taxation that would be necessary to build up a vast new federal law enforcement apparatus also makes such a step less likely. ${ }^{43}$

In short, it may be something of a historical accident that U.S.-style federalism evolved such that states do not only possess formal (albeit somewhat limited) powers, but also a great deal of responsibility for carrying out the day-to-day functions of governance. The narrative is not wholly a happy one; the downsides of relying on states to administer central aspects of governance, such as election administration, are numerous. But the alternative of federal control does increase the worst-case threat of authoritarianism.

II. State Electoral Administration as a Bulwark Against Authoritarianism: The 2020 Election

In the days following the 2020 election, then-President Trump denounced the process of counting legitimate votes and called for it to immediately stop where he was winning and continue where he was losing. ${ }^{44}$ Protesters took to the streets simply to argue for vote counting to proceed, while other armed protesters surrounded county voting headquarters in an attempt to impede the delivery of ballots and the associated vote tallying. ${ }^{45}$ Even after all major news networks had called the election and numerous international leaders had offered their congratulations, the President and the Republican Party (with a few exceptions) refused to concede or provide the resources traditionally available to the President-elect. ${ }^{46}$

The effort continued throughout all phases of the process, up to the final stage on January 6, 2021, when Congress was due to carry through the formality of counting and certifying received electoral votes. ${ }^{47}$ On that day,

42. Cf. John S. Baker, Jr., State Police Powers and the Federalization of Local Crime, 72 TEMP. L. REV. 673, 679 (1999) ('Traditionally, what is labeled 'violent crime,' 'street crime,' or 'local crime' has been the near exclusive responsibility of state and local government.").

43. Cf. Landau, Wiseman \& Wiseman, supra note 8, at 1218-19 (noting that "the vast majority of law enforcement in the United States work at the state and local level," as opposed to the federal level).

44. See Shear et al., supra note 5 and accompanying text; Swan \& Basu, supra note 2 and accompanying text.

45. See, e.g., Maanvi Singh, 'Count Every Vote': Protestors Take to Streets Across US as Ballots Are Tallied, GUARDIAN (Nov. 5, 2020, 5:48 AM) https://www.theguardian.com/usnews/2020/nov/04/protests-votes-ballot-counting-us-election [https://perma.cc/8KSS-XJEA] (noting protests in cities around the United States).

46. Nicholas Fandos \& Emily Cochrane, Republicans Back Trump's Refusal to Concede, Declining to Recognize Biden, N.Y. TIMES (Nov. 9, 2020), https://www.nytimes.com/2020/11/09/us /politics/republicans-trump-concede-2020-election.html [https://perma.cc/A4HE-ZBH8].

47. See Cong. Research Serv., Counting Electoral Votes: AN Overview of Procedures at the Joint Session, InCluding ObJections by Members of Congress 1 
President Trump held a massive rally outside the White House, where he incited a mob to march on the Capitol. ${ }^{48}$ The mob invaded the Capitol, erected a gallows outside it, and symbolically sought to hang leaders such as Vice President Mike Pence. ${ }^{49}$ Through these and other moves, the perpetrators carried out violent actions that desecrated the seat of American government and led to at least five deaths, including a capitol police officer. ${ }^{50}$ Needless to say, these are hallmarks of a substantial erosion of democracy and the growth of authoritarianism. ${ }^{51}$

During his four years in office, President Trump also made statements that alarmed scholars and commentators as paving the way for a potential move towards authoritarianism. He attempted to block efforts to investigate Russian meddling in the 2016 U.S. election. ${ }^{52} \mathrm{He}$ successfully shortened census counting, thus affecting states' representation in Congress $;{ }^{53}$ his Secretary of Commerce also unsuccessfully attempted to insert a citizenship question into the census - another factor that likely would have affected census responses and state representation. ${ }^{54} \mathrm{He}$ attempted to limit the funding of the U.S. Postal Service during a period of expansive voting by mail, and he made

(2020), https://fas.org/sgp/crs/misc/RL32717.pdf [https://perma.cc/PZN7-DNLT] (describing the electoral certification process and its 2021 date).

48. Philip Rucker \& Josh Dawsey, Trump Defiant and Unapologetic About His Role in Inciting Capitol Mob Attack, WASH. POST (Jan. 12, 2021, 5:17 PM), https://www.washingtonpost.com/politics/trump-defiant-mob/2021/01/12/b93231bc-54f8-11eb-a817-e5e7f8a406d6_story.html [https://perma.cc/DR99-ZTQP].

49. See Brandon T. Jett \& Allison Robinson, The Chilling Similarities Between the Pro-Trump Mob and Lynchings a Century Ago, WASH. POST (Jan. 15, 2021, 5:00 AM), https://www.washingtonpost.com/outlook/2021/01/15/chilling-similarities-between-pro-trump-mob-lynchings-centuryago/ [https://perma.cc/L7C5-L7MG] (describing and showing the gallows and noose outside of the capitol and chants of "Hang Mike Pence!").

50. Jack Healy, These Are the Five People Who Died in the Capitol Riot, N.Y TIMES (Jan. 11, 2021), https://www.nytimes.com/2021/01/11/us/who-died-in-capitol-building-attack.html [https://perma.cc/WTQ9-6RRD].

51. See LEVITSKY \& ZIBLATT, supra note 11 and accompanying text.

52. Quinta Jurecic, Obstruction of Justice in the Mueller Report: A Heat Map, LAWFARE (April 21, 2019, 2:32 PM), https://www.lawfareblog.com/obstruction-justice-mueller-report-heat-map [https://perma.cc/VD5G-UGFX] (describing the Mueller Report's assessment of whether President Trump obstructed justice in the investigation into Russia's election interference),

53. See Ross v. Nat'l Urban League, 141 S. Ct. 18, 18-19 (2020) (staying a preliminary injunction that would have required continued data collection due to "operational disruptions caused by the COVID-19 pandemic"); Press Release, Steven Dillingham, Director, U.S. Census Bureau, Statement from U.S. Census Bureau Director Steven Dillingham: Delivering a Complete and Accurate 2020 Census Count (Aug. 3, 2020), https://www.census.gov/newsroom/press-releases/2020/delivering-complete-accurate-count.html [https://perma.cc/R6Z9-CG2P] ("We will end field data collection by September 30, 2020. Self-response options will also close on that date to permit the commencement of data processing.").

54. Dep't of Commerce v. New York, 139 S. Ct. 2551, 2576 (2019) (invalidating the citizenship question insertion to the extent that the agency failed to provide adequate explanation for its action). 
extensive comments denigrating voting by mail as allegedly beset by fraud. ${ }^{55}$ Indeed, Trump knew that the mail-in vote would be dominated by Democrats in many key states, due in large part to his dismissive attitude towards the COVID-19 pandemic and his baseless attacks on the integrity of mail-in voting. ${ }^{56}$

Despite these many efforts to curb the democratic voting process, voters were able to cast ballots in record numbers in the midst of the worst pandemic in recent history. ${ }^{57}$ Voter turnout as a percentage of the voter eligible population was at its highest level since $1900 .{ }^{58}$ Many counties across the United States made herculean efforts to ensure that voters could vote and that their vote would count. They constructed and made available secure ballot drop boxes. In some cases they ensured - at the requirement of their states - that an official representative continuously monitored these drop boxes. ${ }^{59}$ They sent out and processed thousands of mail-in ballots, provided curbside and

55. President Trump stated:

Democrat officials never believed they could win this election honestly. I really believe that. That's why they did the mail-in ballots, where there's tremendous corruption and fraud going on. That's why they mailed out tens of millions of unsolicited ballots without any verification measures whatsoever. And I've told everybody that these things would happen, because I've seen it happen . . . . And I tell you, I would — I have been talking about this for many months with all of you. And I've said very strongly that mail-in ballots are going to end up being a disaster. Small elections were a disaster.

Trump, supra note 1.

56. Elizabeth Bauer, Separating Fact from Fiction on Trump and the Post Office - And Why It Matters, FORBES (Aug. 16, 2020, 9:42 AM), https://www.forbes.com/sites/ebauer/2020/08/16/separating-fact-from-fiction-on-trump-and-the-post-officeand-why-it-matters/?sh=49a0b5323d 74

[https://perma.cc/2P6Y-M5V7] (quoting an interview with Fox Business in which President Trump stated: "[The Postal Service] want[s] \$3.5 billion for something that will turn out to be fraudulent, that's election money basically. They want $\$ 3.5$ trillion—billion dollars for the mail-in votes, OK, universal mail-in ballots, $\$ 3.5$ trillion").

57. Olivia B. Waxman, The 2020 Election Set a Record for Voter Turnout. But Why is it Normal for So Many Americans to Sit Out Elections?, Time (Nov. 5, 2020, 9:24 AM), https://time.com 15907062/record-turnout-history/ [https://perma.cc/9M29-FNJR] ("More Americans voted in 2020 - and voted by mail - than in any other election in U.S. history.").

58. Kevin Schaul, Kate Rabinowitz \& Ted Mellnick, 2020 Turnout Is the Highest in Over a Century, WASH. POST (Nov. 5, 2020), https://www.washingtonpost.com/graphics/2020/elections /voter-turnout/ [https://perma.cc/GP68-4KJ7].

59. See, e.g., Ian Lenahan, For the First Time, Absentee Drop Boxes Are in Play for New Hampshire's 2020 Elections, CONCORD MONITOR (Oct. 23, 2020, 5:43 PM), https://www.concordmonitor.com/For-the-first-time-absentee-drop-boxes-are-in-play-for-New-Hampshire-s-2020-elections36941756 (noting New Hampshire's first-time use of absentee ballot drop boxes, all of which were "staffed by a municipal employee"); VOPP: Table 9: Ballot Drop Box Definitions, Design Features, Location and Number, NAT'L CONFERENCE OF STATE LEGISLATURES (Aug. 18, 2020), https:// www.ncsl.org/research/elections-and-campaigns/vopp-table-9-ballot-drop-box-definitions-designfeatures-location-and-number.aspx [https://perma.cc/27EF-KHNQ] (describing states' design requirements for ballot boxes and requirements for county and other municipal officials). 
drive-through voting opportunities, and, in many cases, encouraged residents to vote and provided detailed information on how to vote. ${ }^{60}$

Other counties and states attempted to curtail votes or were incompetent in administering a complex voting process in the midst of the pandemic. Texas notoriously limited Harris County, which includes Houston, to one ballot drop box. ${ }^{61}$ Some counties in Ohio delegated absentee-ballot mailing to a private vendor, which happened to be owned by a supporter of President Trump, that delayed the mailing of "hundreds of thousands of absentee ballots. ${ }^{, 62}$ Ballot printing back-ups and mailing problems similarly delayed voting in other counties and states; this, compounded with U.S. Postal Service delays, caused many voters to miss the deadlines for returning their ballots. ${ }^{63}$ In races with extremely thin margins, these types of procedures and mistakes could have tilted the election results toward Biden or Trump.

But amidst the imperfections of the highly decentralized U.S. electoral process, one should also consider the ways in which the sometimes messy process of state- and county-run federal elections may have helped to prevent rapid moves towards authoritarianism. Despite President Trump's bluster, he was unable to do much to influence either the design of electoral rules or the

60. See, e.g., Trinady Joslin, For Nearly 3 Million Disabled Texans, Voting This Year is Even Harder, TEX. TRIB. (Oct. 30, 2020, 5:00 AM), https://www.texastribune.org/2020/10/30/texas-voting-disability/ [https://perma.cc/F9GF-5A9Z] (noting that every county in Texas was required to offer curbside voting); Becca Savransky, 'Astonishing': Record Numbers of King County Voters Turning in Ballots Early, SEATTLE POST (Oct. 22, 2020, 7:47 PM), https://www.seattlepi.com/seattlenews/article/Astonishing-Record-numbers-of-King-County-15667522.php

[https://perma.cc/FA57-B9KH] (noting more than 195,000 ballots returned to county drop boxes and that "[e]lections officials are continuing to empty ballot boxes regularly, and are able to respond quickly to any reports of ballot boxes getting full.”); Curbside Voting, TEX. SEC'Y OF STATE, https:// www.sos.state.tx.us/elections/forms/covid/curbside-voting-a-english.pdf [https://perma.cc/7TBBKD7A] (noting counties' provision of curbside voting for individuals with COVID-19 signs or symptoms).

61. Abbott v. Anti-Defamation League Austin, 610 S.W.3d 911 (Tex. 2020) (per curiam) (affirming the validity of an order limiting ballot drop boxes to one per county).

62. Doug Livingston, Absentee Ballot Mailings Delayed in Summit and Other Ohio Counties, AKRON BEACON J. (Oct. 8, 2020, 3:48 PM), https://www.beaconjournal.com/story/news/2020/10/08/absentee-ballot-mailings-delayed-summit-cuyahoga-and-18-othercounties/5925499002/ [https://perma.cc/ND4X-NQNM]; see also Reid J. Epstein, In Ohio, a Printing Company Is Overwhelmed and Mail Ballots Are Delayed, N.Y. TiMEs (Oct. 16, 2020), https://www.nytimes.com/2020/10/16/us/politics/ohio-mail-ballots-trump.html [https://perma.cc/E2SZ-GR57].

63. See, e.g., Jacob Bogage \& Christopher Ingraham, USPS Processed 150,000 Ballots After Election Day, Jeopardizing Thousands of Votes, WASH. POST (Nov. 6, 2020, 1:00 PM), https:// www.washingtonpost.com/business/2020/11/05/usps-late-ballots-election/ [https://perma.cc/UCU4-97TE] (noting that "[m]ore than 150,000 ballots were caught in U.S. Postal Service processing facilities Wednesday and not delivered by Election Day"); Annie Grayer, Voters Wait on Delayed Mail-in Ballots as Election Day Nears, CNN (Oct. 22, 2020, 8:20 AM), https:// www.cnn.com/2020/10/22/politics/voting-by-mail-ballot-delays/index.html [https://perma.cc/G4ZT-5RZZ]. 
counting of ballots - processes controlled by state and local officials over whom he had no direct authority. Imagine, instead, a hypothetical scenario in which a "Federal Electoral Commission" or "Tribunal" controlled voter registration, the process of voting, and the process of vote counting. If a president were able to capture such an agency - and it is difficult to imagine that President Trump would not have at least attempted to do so- the risks of a rigged or tilted voting process would increase substantially.

To be clear, we do not argue here that the protections provided by the U.S. system are foolproof. Indeed, the conduct of the election itself suggests ways in which a determined authoritarian might find choke points within state processes and federal workarounds to skirt state-based democratic protections. The 2020 election highlighted several of these dangers.

One problem - as we have already noted - is that while the U.S. electoral system is highly decentralized, it is often poorly insulated from partisan pressure. ${ }^{64}$ Indeed, many election officials are already highly partisan. This may lower the costs of capturing any particular election official. Compounding this risk is the byzantine nature of U.S. election processes, which creates a number of different potential actors who can be captured to delay or alter results. ${ }^{65}$ Consider, for example, the way that President Trump's allies

64. See, e.g., David C. Kimball, Martha Kropf, Donald Moynihan, Carol L. Silva \& Brady Baybeck, The Policy Views of Partisan Election Officials, 3 U.C. IRVINE L. REV. 551, 552, 552 n.6 (2013) (arguing that decentralization does not insulate elections from partisan politics by state election officials); Daniel P. Tokaji, The Future of Election Reform: From Rules to Institutions, 28 YALE L. \& POL'Y REV. 125, 141 (2009) (same).

65. One way for a determined Executive to influence the vote would be to attempt to interfere in the actual voting and vote tallying process. There is no evidence of this having occurred in the 2020 election, although there do appear to have been some party-based efforts that confused voters, such as Republican state and county entities installing unauthorized ballot boxes in California. See Letter from Alex Padilla, Cal. Sec'y of State, to Jessica Patterson, Chair, Cal. Republican Party; Fred Vanderhoof, Chairman, Fresno Cnty. Republican Party; Fred M. Whitaker, Chairman, Republican Party of Orange Cnty.; Dr. Richard Sherman, Chairman, L.A. Cnty. Republican Party (Oct. 12, 2020), https://files.constantcontact.com/c1d64240601/cf61386b-2497-47a3-8556b5dba186f486.pdf [https://perma.cc/KH4R-GTTX] (describing complaints, "including photographs and reports of unauthorized drop boxes" in Fresno, Orange, and Los Angeles County, some of which were misleadingly labeled as "Secure Ballot Dropoff Location" and "approved and bought by the GOP," and ordering the state GOP and county GOPs to "cease and desist the coordination, use an/or false or misleading promotion of unauthorized and non-official vote by mail drop boxes"). For literature on possible routes for the Executive's party to potentially interfere with the voting and vote counting processes and mechanisms protecting against this, see, for example, Frank Emmert, Christopher Page \& Antony Page, Trouble Counting Votes? Comparing Voting Mechanisms in the United States and Selected Other Countries, 41 CREIGHTON L. REV. 3, 18, 18, n. 77 (2007) (noting "de facto delegation of vote counting to the private companies supplying the voting machines, such as Election Systems \& Software ('ES \& S'), Premier Election Solutions (formerly Diebold Election Systems)" in the United States, and noting that these companies have links to specific political parties); Rebecca Green, Rethinking Transparency in U.S. Elections, 75 OHIO ST. L.J. 779, 810-11 (2014) (noting increasingly public election records after Bush v. Gore, allowing, for example, the 
attempted to leverage vote certification processes through which counties and states canvass votes - meaning provide unofficial election returns - and then formalize these returns by certifying them to the state. ${ }^{66}$

This was most dramatic in Michigan, where both county and state canvassing boards are equally divided between Republican and Democratic partisans. ${ }^{67}$ After the two Republicans on the Wayne County Board initially refused to certify and then backtracked under intense pressure at a hearing, then-President Trump called one of them, and both Republicans then attempted to recant their certification. ${ }^{68}$ Trump also attempted to pressure the state canvassing board, although it ultimately voted 3-0 (with one Republican abstention) to certify. ${ }^{69}$ Michigan's established law states that canvassing

public posting of disputed ballots and public viewing of some vote recounts, but maintaining skepticism about adequate transparency); Allison R. Hayward, Bentham \& Ballots: Tradeoffs Between Secrecy and Accountability in How We Vote, 26 J.L. \& POL. 39, 58 (2010) (with mail-in ballots, noting the possibility that even for mail-in systems with strict affidavit provisions, a "willing notary" could allow fraud); Nathaniel Persily, "Celebrating" the Tenth Anniversary of the 2000 Election Controversy: What the World Can Learn from Recent Election Dysfunction in the United States, 44 IND. L. REV. 85, 107-08 (2010) (defining fraud and describing ways in which it can occur).

66. The fifty states all have different requirements for this process. These varied statutes place deadlines by which counties must canvass votes - meaning provide unofficial election returns - and then formalize these returns by certifying them to the state. The state then canvasses and certifies the votes. After the Voting Ends: The Steps to Complete an Election, NAT'L CONFERENCE OF STATE LEGISLATURES (Oct. 28, 2020), https://www.ncsl.org/research/elections-and-campaigns/after-thevoting-ends-the-steps-to-complete-an-election.aspx [https://perma.cc/ZSL6-H3FD].

67. Mich. Dep't of State, Bureau of Elections, Manual for Boards of County CANVASSERS 1 (2020), https://www.michigan.gov/documents/sos/BCC_Manual_464331_7.pdf [https://perma.cc/Z6BE-NFL4].

68. For descriptions of the call, see, for example, David A. Fahrenthold, Beth Reinhard, Elise Viebeck \& Emma Brown, Trump's Escalating Attacks Put Pressure on Voter Certification Process, WASH. POST (Nov. 19, 2020, 7:14 PM), https://www.washingtonpost.com/politics/trumps-escalating-attacks-put-pressure-on-vote-certification-process/2020/11/19/42f5fd76-2aa5-11 eb-8fa2-

06e7cbb145c0_story.html [https://perma.cc/S6KL-CXKS]; Clara Hendrickson, Donald Trump Called Monica Palmer After Wayne County Board of Canvassers Meeting, DetrolT FreE PRESS (Nov. 19, 2020, 10:40 AM), https://www.freep.com/story/news/local/michigan/detroit/2020/11/19 /trump-monica-palmer-wayne-canvassers-certification-election/3776190001/

[https://perma.cc/28JP-NX34]. President Trump and other members of the Republican Party also used social media to attempt to influence county-level certification. After Republican members of the Wayne County Board of Canvassers initially refused to certify the election results for Biden, President Trump tweeted, "Wow! Michigan just refused to certify the election results! Having courage is a beautiful thing." The Michigan Republican Party Chairwoman stated, "I am proud that, due to the efforts of the Michigan Republican Party, the Republican National Committee and the Trump Campaign, enough evidence of irregularities and potential voter fraud was uncovered resulting in the Wayne County Board of Canvassers refusing to certify their election results." Complaint for Declaratory and Injunctive Relief at 128 , Mich. Welfare Rights Org. v. Donald J. Trump, No. 1:20-cv-03388 (D.D.C. filed Nov. 20, 2020), 2020 WL 6826533.

69. Complaint for Declaratory and Injunctive Relief, supra note 68, at 29; Craig Mauger \& Melissa Nann Burke, Michigan Board Certifies Nov. 3 Election, Cementing Biden Victory, DETROIT NEws (Nov. 23, 2020, 12:37 PM), https://www.detroitnews.com/story/news/politics/2020/11/23 /michigan-election-state-canvassers-certification/6390475002/ [https://perma.cc/9ZCF-3B5U]. 
boards have duties that are "purely ministerial and clerical," and that they are bound by the returns and cannot investigate them to seek out fraud. ${ }^{70}$ While this jurisprudential principle may have reduced the likely impact of a deadlocked vote, the design of the Michigan process and the political pressure brought to bear on it raised justifiable concerns. ${ }^{71}$

In the future, there is clearly a risk that extreme partisan actors will work harder to capture state or local officials. This might be done through stacking canvassing boards or similarly obscure institutions such as those found in Michigan. Or, even more frighteningly, it might involve efforts to elect QAnon sympathizers or similar extremists to prominent election offices such as secretaries of state. The refusal of some key Republican actors-such as the Georgia Secretary of State - to alter or meddle with election results could easily be reversed should some of these offices fall into hyperpartisan hands. $^{72}$

Another kind of workaround is to find the centralized piece of an otherwise decentralized process. President Trump may have pinpointed such an element in attempting to radically undermine the U.S. Postal Service during an election in which voting would occur heavily by mail, and in whichbecause of his criticisms of mail-in ballots - it was virtually guaranteed that mail-in votes would tilt heavily against him. ${ }^{73}$ The moves by Postmaster General Louis DeJoy to, for example, dismantle a large number of mail sorting

70. McQuade v. Furgason, 51 N.W. 1073, 1073 (Mich. 1892) (per curiam). Thus, even when county inspectors in Michigan alleged that a precinct had unlawfully allowed outsiders to go into booths with non-incapacitated voters - including an outsider who "fixed the ballots, and saw that they were cast as prepared by him," because a County Board of Canvassers certified the results, the Board of State Canvassers had to accept them. Id. In Michigan, voters may address purported fraud through a quo warranto process after certification, rather than by blocking certification. Costantino v. City of Detroit, 950 N.W.2d 707, 708 (Mich. 2020) (Zahra, J., concurring) (citing MiCH. COMP. LAWS $\S 168.861$ and cases addressing the quo warranto action).

71. Shortly after meeting with President Trump at the White House, the Michigan Speaker of the House stated that a deadlock could lead to a "constitutional crisis" where it would be unclear who had authority to select electors. See Craig Mauger, Michigan Speaker Floats Possibility of 'Constitutional Crisis,' DeTROIT NEws (Nov. 22, 2020, 11:17 AM), https://www.detroitnews.com /story/news/politics/2020/11/22/michigan-house-speaker-floats-possibility-constitutional-crisis /6381960002/ [https://perma.cc/UK2J-8UX9].

72. See $3^{\text {rd }}$ Strike Against Voter Fraud Claims Means They're Out After Signature Audit Finds No Fraud, GA. SEC'Y OF STATE, https://sos.ga.gov/index.php/elections/3rd_strike_against_voter fraud claims means theyre out after signature audit finds no fraud [https://perma.cc/33L344MP] (Georgia Secretary of State Brad Raffensperger after the Georgia recount stated: "The Secretary of State's office has always been focused on calling balls and strikes in elections, and, in this case, three strikes against the voter fraud claims and they're out.")

73. Michael D. Shear, Trump Again Assails Mail-in Voting, N.Y. TIMES (Aug. 3, 2020), https:// www.nytimes.com/2020/08/03/us/politics/trump-mail-in-voting.html [https://perma.cc/NA29ALQY] (noting numerous repeated statements by President Trump casting mail-in ballots as fraudulent). 
machines, did have a notable impact on mail delivery in the months surrounding the election. ${ }^{74}$ Indeed, more than 150,000 ballots were at risk of being thrown out by election officials due to mailing delays. ${ }^{75}$ But media and congressional scrutiny seem to have prevented the problem from becoming worse, and many voters also seemed to adjust their behavior by sending ballots in earlier or utilizing drop boxes. ${ }^{76}$ Of course, both the partisan tilt and sheer volume of mail ballots may reduce in future elections, which presumably will not be conducted in the thick of a pandemic.

Another potential route around the decentralized elections system is recourse to the federal judiciary, particularly the Supreme Court, as a means of undoing the election. ${ }^{77}$ The pandemic heightened this risk by forcing states to make changes to their voting rules. Given that many states did so through executive and judicial action, the risk again increased because of the reasoning employed by Chief Justice Rehnquist in Bush v. Gore: ${ }^{78}$ that the Election Clause gives power to the "state legislature," not the state as such. ${ }^{79}$ This, in turn, gives potential warrant to the Supreme Court to forgo its usual deference in interpreting state law, and instead to police whether state executive or judicial determinations depart so radically from existing state election law that they are making, rather than interpreting, that law. Republicans opposing election results raised this argument in a number of cases surrounding the

74. Andrew Solender, Reports of Dismantled USPS Sorting Machines Continue Despite DeJoy Announcing Halt, FORBES (Aug. 19, 2020, 2:14 PM), https://www.forbes.com/sites/andrewsolender /2020/08/19/reports-of-dismantled-usps-sorting-machines-continue-despite-dejoy-announcing-halt /?sh=323ab0a426b9 [https://perma.cc/L8A9-V8KF].

75. Bogage \& Ingraham, supra note 63.

76. See Pam Fessler, Ballot Drop Boxes Become Latest Front in Voting Legal Fights, NPR (Aug. 11, 2020, 5:01 AM), https://www.npr.org/2020/08/11/901066396/ballot-drop-boxes-become-latest-front-in-voting-legal-fights [https://perma.cc/HVR9-R6RV] (describing drop boxes' popularity); Solender, supra note 74 (noting that the Postmaster General halted the disassembly of machines, although in some cases too late). But see Bogage \& Ingraham, supra note 63 (noting that the U.S. Postal Service delivered approximately 150,000 ballots the day after the election).

77. Indeed, in 2020, the U.S. Supreme Court determined that votes mailed before Election Day but received after Election Day could not be counted in Wisconsin, and it addressed numerous other challenges to state and county election procedures. Democratic Nat'l Comm. v. Wis. State Legislature, 141 S. Ct. 28 (2020) (mem.) The Court invalidated a U.S. district court-ordered "six-day extension of the receipt deadline for mail ballots postmarked by Election Day," as summarized by the dissent, and describing other challenges also decided by the Court in 2020. Id. at 40 (Kagan, J., dissenting).). President Trump repeatedly asserted that he would go to the Supreme Court to vindicate the election that he believed he had won. See, e.g., Morgan Chalfant \& Brett Samuels, Trump Prematurely Declares Victory, Says He'll Go to Supreme Court, Hill (Nov. 4, 2020, 2:57 AM) https:/thehill.com/homenews/campaign/524404-trump-says-hell-go-to-supreme-court-to-stopvotes-from-being-counted [https://perma.cc/MLF9-AR2D] (quoting President Trump as stating: "This is a major fraud on our nation. We want the law to be used in a proper manner. So we'll be going to the U.S. Supreme Court. We want all voting to stop.").

78. 531 U.S. 98 (2000).

79. Id. at 112-13 (Rehnquist, C.J., joined by Scalia \& Thomas, JJ., concurring). 
2020 election, particularly those where state courts or executives extended deadlines for receipt of mail-in ballots. The Supreme Court has agreed with this argument in dicta in at least one case. ${ }^{80}$

While the literature often conceptualizes courts, both in the United States and comparatively, as defenders of the democratic order, in fact they have frequently aided authoritarian actors in consolidating power across the world. ${ }^{81}$ But in the short run, problematic judicial interventions in U.S. elections seem far more plausible at the margins. The vote-by-mail deadline issue, for example, would not have come close to swinging any decisive state. And it may be that the unique context of the 2020 election, during the most significant pandemic to occur in more than a century, heightened what would normally be a much lower risk of federal judicial intervention into state election law, and one which fortunately did not materialize.

Indeed, the Trump campaign's legal challenges were overwhelmingly unsuccessful in both state and federal courts. ${ }^{82}$ The Trump campaign and its allies filed at least sixty-two lawsuits challenging election results in various states and won only one (insignificant) legal victory. ${ }^{83}$ Perhaps most dramatically, the bizarre lawsuit filed by Texas and seventeen other states to challenge results in a handful of swing states was denied in a three-sentence order for lack of standing based on the failure to show a "a judicially cognizable interest in the manner in which another State conducts its elections." 84

A final "centralized" element in the decentralized U.S. elections process is the certification and counting of votes by the Congress itself, governed by the Twelfth Amendment and the "confusing" and "unwieldy" procedures of

80. See Republican Party of Pa. v. Boockvar, 141 S. Ct. 1, 2 (2020) (mem.) ("The provisions of the Federal Constitution conferring on state legislatures, not state courts, the authority to make rules governing federal elections would be meaningless if a state court could override the rules adopted by the legislature simply by claiming that a state constitutional provision gave the courts the authority to make whatever rules it thought appropriate for the conduct of a fair election."). For another case in which parties propounded this Bush v. Gore argument, see Emergency Application for a Stay Pending the Filing and Disposition of a Petition for a Writ of Certiorari, Scarnati v. Pa. Democratic Party, 141 S. Ct. 644 (2020) (mem.) (No. 20A53), 2020 WL 5898732.

81. David Landau \& Rosalind Dixon, Abusive Judicial Review: Courts Against Democracy, 53 U.C. DAVIS L. REV. 1313, 1316 (2020).

82. See Alan Feuer \& Zach Montague, Over 30 Trump Campaign Lawsuits Have Failed. Some Rulings are Scathing, N.Y. TIMES (Nov. 25, 2020), https://www.nytimes.com/2020/11/25/us/elections/trump-campaign-lawsuits.html [https://perma.cc/6FDL-MV8N].

83. See William Cummings, Joey Garrison \& Jim Sergent, By The Numbers: President Donald Trump's Failed Efforts to Overturn the Election, USA TODAY (Jan. 6, 2021, 4:01 AM), https:// www.usatoday.com/in-depth/news/politics/elections/2021/01/06/trumps-failed-efforts-overturnelection-numbers/4130307001/ [https://perma.cc/6WG7-NL34].

84. See Texas v. Pennsylvania, No. 155, ORIG., 2020 WL 7296814, at*1 (U.S. Dec. 11, 2020) (mem.). 
the Electoral Count Act. ${ }^{85}$ These were the events that precipitated the mob invasion on January 6, 2021. Here too, former President Trump attempted to apply pressure, both by working backroom channels and by whipping up and inciting the mob. Most ominously, he tried to pressure former Vice President Pence, in his role as presiding officer of the session, into unilaterally refusing to count electoral votes from a number of states that Trump baselessly contested. ${ }^{86}$ It is dismaying that even after the violent mob descended on the capitol, delaying the session for several hours, 139 Republican members of the House (and eight Republican Senators) joined unfounded objections to at least one state's electoral results. ${ }^{87}$ But the relatively late date of the objection, after all election results had been certified and electoral votes cast, may have reduced the likelihood that the process could actually have been used to baselessly reverse the election. Further, we should reemphasize the limited nature of our argument: Our broad point is not that the particular characteristics of U.S. federalism make authoritarian moves impossible, but simply slower and more difficult.

\section{Costs of U.S. Federalism and the Second-Best Solution}

The literature critiquing U.S. federalism is legion. ${ }^{88}$ Here, we content ourselves with considering a few important problems that have been highlighted by the recent election: the risk of localized tyranny within subnational jurisdictions, the risk of inefficiency, and the threat that the central governments will use the existence of the states to shift blame. Each of these problems is well known; we do not deny their importance here, but do aim to show that they are consistent with U.S. federalism as a "second-best" solution. While extreme decentralization of functions tends to prevent best-case outcomes, it also acts as a kind of insurance mechanism that makes worstcase outcomes less likely.

85. See Nathan L. Colvin \& Edward B. Foley, Lost Opportunity: Learning the Wrong Lessons from the Hayes-Tilden Dispute, 79 FORDHAM L. REV. 1043, 1044 (2010) (arguing that the Electoral Count Act represented a lost opportunity that did not solve all the constitutional problems posed by the disputed 1876 Hayes-Tilden election and the Twelfth Amendment, and that Congress missed an opportunity to respond more effectively with an Electoral Commission or another more sweeping solution).

86. See Michael S. Schmidt, Trump Says Pence Can Overturn His Loss in Congress. That's Not How It Works., N.Y. TIMES (Jan. 5, 2021), https://www.nytimes.com/2021/01/05/us/politics/pencetrump-election.html [https://perma.cc/2BVK-TH7N].

87. Karen Yourish, Larry Buchanan \& Denise Lu, The 147 Republicans Who Voted to Overturn Election Results, N.Y. TIMES (Jan. 7, 2021), https://www.nytimes.com/interactive/2021/01/07/us /elections/electoral-college-biden-objectors.html [https://perma.cc/ZR7J-TR6F].

88. See, e.g., Malcom M. Feeley \& Edward Rubin, Federalism: Political IdENTITY AND TrAgic Compromise 20-29 (2008); Edward L. Rubin \& Malcolm Feeley, Federalism: Some Notes on a National Neurosis, 41 UCLA L. REV. 903, 907-09 (1994) (arguing that decentralization can achieve many of the values purportedly unique to federalism). 


\section{A. Localized Tyranny and Oppression}

One of the most durable critiques of federalism notes that it provides states space to repress minority groups within their jurisdiction. ${ }^{89}$ U.S. history, of course, offers many examples of that phenomenon; witness the historic discrimination, and then resistance to civil rights such as desegregation, practiced in the southern United States for a long period of time. ${ }^{90}$ Indeed, southern states were particularly repressive in the election context during the Jim Crow Era, using "poll taxes, literacy tests, registration barriers, intimidation at the polls, or bald violence" to block minority votes. ${ }^{91}$ This kind of tyranny might be more likely at the state rather than federal level for the reasons classically noted by Madison in The Federalist: factions may find it easier to grab unfettered control of the machinery of government on a smaller scale. ${ }^{92}$ State-level rules and constitutions are also often easier to change or manipulate.

Restrictions on voting are one important way in which incumbents in states have tilted the electoral playing field in their favor. Particularly after the Supreme Court's Shelby County v. Holder ${ }^{93}$ decision weakened the Voting Rights Act, ${ }^{94}$ Republican-controlled states passed a raft of stringent voterID laws and other measures that made it more difficult to vote. ${ }^{95}$ The pandemic, of course, pushed this issue to a new level of urgency during the 2020 election. Some states went to great lengths to accommodate voter concerns, for example by expanding early and mail-in voting and easing rules or restrictions on these paths. ${ }^{96}$ Other states were far less accommodating, as

89. See, e.g., THE FEDERALIST Nos. 10, 51, supra note 16 (expressing concerns about how minority interests would fare at the state level); Note, A Madisonian Interpretation of the Equal Protection Doctrine, 91 YALE L.J. 1403, 1404 (1982) (noting states' failures to protect minority rights).

90. See Landau, Wiseman \& Wiseman, supra note 8, at 1192, $1192 \mathrm{n} .18$ (summarizing the problem and providing citations); Ilya Somin, Closing the Pandora's Box of Federalism: The Case for Judicial Restriction of Federal Subsidies to State Governments, 90 GEO. L.J. 461, 473 (2002) (noting southern states' obstinance in the face of federal directives to enforce civil rights).

91. Green, supra note 65 , at 791 n.58.

92. See The Federalist No. 10, supra note 16.

93. 570 U.S. 529 (2013).

94. Id. at 557.

95. See, e.g., Christopher S. Elmendorf \& Douglas M. Spencer, Administering Section 2 of the Voting Rights Act After Shelby County, 115 ColuM. L. REV. 2143, 2145-46 (2015).

96. See, e.g., Vote by Mail, CAL. SEC'Y OF STATE, https://www.sos.ca.gov/elections/voter-registration/vote-mail [https://perma.cc/55FK-GC3M] describing mail-in ballots provided to all voters); N.J. DEP'T OF STATE, Div. OF ElECTIONS, supra note 30 (same). 
evidenced by Texas's notorious limitation on ballot drop boxes to one per county despite substantial U.S. Postal Service delays. ${ }^{97}$

More broadly, recent experience has shown a significant risk that parties gaining full control over state-level government, especially in "swing" states, may use that control to further entrench power. The classic way of doing so is gerrymandering districts to provide the incumbent party with future advantages, but this is only one of several common tools. Consider North Carolina and Wisconsin. In both cases, Republicans won control of state legislatures in 2010 and imposed extreme gerrymanders on both state and federal districts. In 2018, for instance, Republicans won a minority of the vote for the lower house of the Wisconsin state legislature with only $48 \%$ of the vote, but nonetheless took fifty-six of sixty-three seats. ${ }^{98}$ The Wisconsin state legislature also passed important laws greatly weakening public and private-sector unions, which in turn aided the party's efforts to stay in power by undermining a powerful electoral opponent. ${ }^{99}$ Finally, when Democrats won the governorship of both states (in 2016 and 2018, respectively), both legislatures passed a set of laws that changed the balance of the separation of powers, stripping appointment and other powers from the executive branch and instead lodging these authorities with the legislature. ${ }^{100}$

The risk of localized oppression is clearly a significant one. Moreover, especially in an era of very nationalized parties, there is a risk that parties will use their grip on state governments not just to entrench local power, but also to tilt the federal electoral playing field in their favor. If one party were to win the bulk of "swing" states such as North Carolina and Wisconsin, it could use that power to effectively make it more difficult for the other party to win national elections. For this reason, Tom Ginsburg and Aziz Huq

97. See Abbott v. The Anti-Defamation League Austin, 610 S.W.3d 911, 916 (Tex. 2020) (per curiam) (describing and affirming the validity of the governor's order on ballot drop box limits).

98. See Philip Bump, The Several Layers of Republican Power-Grabbing in Wisconsin, WASH. POST (Dec. 4, 2018 11:44 AM), https://www.washingtonpost.com/politics/2018/12/04/several-layers-republican-power-grabbing-wisconsin/ [https://perma.cc/M22W-MGB4].

99. See Frank Manzo IV, Wisconsin Unions Depleted Under Governor Walker, MIDWEST ECON. POL'Y INST. (Sept. 24, 2018), https://midwestepi.org/2018/09/24/wisconsin-unions-depleted-under-governor-walker/ [https://perma.cc/E4DE-G9LN] (describing how Wisconsin Act 10 and "right-to-work" laws have depleted both public and private union membership in the state); Mark Pitsch, Balance of Power: Walker's union proposal could be major setback for state's Democratic Party, WiS. STATE J. (Mar. 7, 2011), https://madison.com/wsj/news/local/govt-and-politics/balance-of-power-walkers-union-proposal-could-be-major-setback-for-states-democraticparty/article_87f6ba78-46c6-11e0-a5fc-001cc4c002e0.html [https://perma.cc/V5XA-YQR8] (““I consider organized labor to be the backbone of the Democratic Party,' said Mike Tate, state party chairman. 'Part of Scott Walker's strategy is to weaken the infrastructure of the Democratic Party."').

100. Maggie Astor, Wisconsin, Limiting Governor, Borrows a Page from North Carolina's Book, N.Y. TIMES (Dec. 5, 2018), https://www.nytimes.com/2018/12/05/us/politics/wisconsin-governor-legal-challenge.html [https://perma.cc/26JF-NXXA]. 
suggest that the impact of federalism on authoritarianism is indeterminate. ${ }^{101}$ Indeed, some have voiced concerns that in the wake of President Trump refusing to concede, Republican states could "appoint electors who ignore the election results and vote for Trump in states he lost." ${ }^{102}$ Alternatively, a state such as Florida could allow former President Trump to operate a "shadow government" through media and other actions over the next four years-a move that would substantially undermine U.S. democracy by causing millions in Trump's loyal following to refute the legitimacy of the duly elected president. ${ }^{103}$ Federalism may slow authoritarian movements by requiring them to capture more entities in order to consolidate power, but the costs of capture may also be lower at the state level.

Our answer to this point is more empirical than theoretical: if one looks around the world, there appear to be a number of cases where seemingly welldesigned apex institutions have been captured, often quite quickly. And the impact of this capture is frequently overwhelming: elections are radically tilted in favor of incumbents, independent media outlets and opposition parties are systematically harassed, and so on. ${ }^{104}$ We do not deny that the impact of one-party capture of state government for antidemocratic ends can be significant. But at the very least, given the rhythm of U.S. elections, that capture will be a slow and gradual process, subject to repudiation by voters along the way. Capture of key individual states can tilt the playing field, but not as dramatically as would be the case if U.S. elections depended only on a single entity, such as a federal electoral tribunal.

\section{B. Inefficiency and Blame Shifting}

Beyond threatening local tyranny, the United States' extremely decentralized variant of federalism often appears to produce inefficient or even arbitrary policy outcomes. The 2020 election arguably provided an example in a context where the fundamental right to vote was in play. The ease with which citizens could vote in the election depended significantly on their state, with little federal guidance or legislation.

101. See Aziz Huq \& Tom Ginsburg, How to Lose a Constitutional Democracy, 65 UCLA L. REV. 78, 160-62 (2018).

102. Leonhardt, supra note 13.

103. See Thomas B. Edsall, Opinion, What is Trump Playing At?, N.Y. TimES (Nov. 11, 2020), https://www.nytimes.com/2020/11/11/opinion/trump-concession-transition.html?auth=loginemail\&login=email [https://perma.cc/YZ2F-L2YA] (quoting Princeton history professor Sean Wilentz's concerns about "a kind of Trumpian government in exile, run from Mar a Lago or maybe from wherever else Trump selects to reside in, in order to avoid prosecution by the State of New York").

104. See generally Landau, Wiseman \& Wiseman, supra note 8 (documenting the recent erosion of democracy in a number of countries, such as in Poland, Russia, Hungary, and Venezuela). 
Despite these flaws, in many cases the inefficiency of U.S. federalism serves as a second-best - and a very important second-best, at that: It is clearly suboptimal when compared to of the potential for coordinated and effective federal action, but it also provides a kind of insurance mechanism against very bad policy outcomes. An effective or coordinated federal election law covering these issues may have been quite helpful, for example, in mandating or providing funding for greatly expanding mail-in voting or in standardizing rules about issues such as ballot receipt dates and counting. But federal law could also have played a counterproductive role; for example, federal officials could have restricted early or mail-in voting and counting despite the pandemic, as some Republican proposals sought to do ${ }^{105}$ And in the absence of a coordinated federal response, state and local governments provided a second-best solution by providing important accommodations in many cases. While "blue" states tended to provide the most sweeping changes to accommodate the right to vote, ${ }^{106}$ key changes were also made in some "red" states. ${ }^{107}$

A related danger of relying on states to carry out key governance functions such as election administration is that it facilitates blame-shifting by federal officials towards the states. The aftermath of the 2020 election has provided a dramatic example. Former President Trump has repeatedly and falsely insisted that there is rampant voter fraud in some states and localities, despite a complete absence of empirical evidence. In the wake of the election, he accused states of taking illegal "ballot dumps" and purposefully doublecounting Democratic ballots. ${ }^{108}$ This castigation of a system beyond the

105. See Jeremy Stahl, Republican Senator Proposes Bill That Would Make It Illegal to Count Votes, SLATE (Sept. 24, 2020, 6:05 PM), https://slate.com/news-and-politics/2020/09/republicansenator-bill-illegal-mail-vote-count-deadline.html [https://perma.cc/6ZCW-SJL9] (describing the V.O.T.E.R. Act sponsored by Senator Rick Scott, which would have disqualified mail-in ballots arriving after Election Day, prevented mail-in ballots received prior to Election Day from being counted until the morning of Election Day, and required all votes to be counted within twenty-four hours of poll closing).

106. See Voting Laws Roundup 2020, BRENNAN CTR. FOR JUSTICE (Dec. 8, 2020), https://www.brennancenter.org/our-work/research-reports/voting-laws-roundup-2020-0 [https://perma.cc/M53M-4KQR] (listing seven states that enacted expansive voting laws protecting the right to vote, of which six were Democrat-controlled states).

107. See Paul Flahive, 'It's Ridiculous': States Struggle To Accommodate COVID-19 Positive Voters, NPR (Aug. 9, 2020, 7:01 AM), https://www.npr.org/2020/08/09/900317332/it-s-ridiculousstates-struggle-to-accommodate-covid-positive-voters [https://perma.cc/K2R2-P2RY] (noting that all states have made some accommodations, although they varied sharply); Patrick Svitek, Gov. Greg Abbott Extends Early Voting for November Election by Six Days, Starting Oct. 13, TEX. TRIB. (July 27, 2020, 4:00 PM), https://www.texastribune.org/2020/07/27/texas-greg-abbott-early-voting-november/ [https://perma.cc/4GXY-XWP6].

108. Jack Brewster, Trump Renews Ballot 'Dump' Conspiracy Theory Claim-Here's Why It's Bogus, FORBES (Nov. 30, 2020, 4:48 PM), https://www.forbes.com/sites/jackbrewster 
control of the Executive is particularly problematic in the context of voting. The ability of the president to shake voters' confidence in the accuracy of electoral results could pave the way for an illegitimate power grab. It is worth noting, however, that a plausible outcome of a more centralized system would have been an illegitimate power grab through direct interference with the voting and vote-counting processes.

While the blame shifting problem is a real one, we again think it needs to be put in context as a "second best." With respect to the pandemic response, the existence of the states may have decreased federal will to take action, but even absent the states there is no guarantee that the Trump administration would have acted vigorously or competently. With respect to voting, it is clearly dangerous for an executive to persuade a large segment of the population that the entire voting system is illegitimate. But it would be much worse for the Executive to administer a centralized election system. Because the Executive can only cast blame on - not directly control - the state election system, his powers to upend the system are somewhat limited. The 2020 election has been a test of the extent and magnitude of those powers.

\section{Conclusion}

U.S. federalism without question imposes costs. But we think it also provides a unique benefit that has been on display in the aftermath of the 2020 election: protection against the kinds of moves towards authoritarianism that have recently occurred in many countries around the world. The dispersal of core functions, including judging, law enforcement, and (as this essay has emphasized) electoral administration, likely acts as a bulwark that slows moves towards authoritarianism.

Our argument is not that the U.S. system is ideal, and indeed one of the goals of our analysis is to highlight avenues for reform. In Part I, we outlined two different ways to protect core functions like electoral administrationinsulating them in centralized institutions (as many other countries do) and decentralizing them (as in the United States). The two logics could be combined by creating institutions that are both quite decentralized and independent, unlike the highly partisan, localized electoral administration found across much of the United States, such as in the Michigan canvassing boards or partisan secretaries of state. Creating more independent local electoral institutions would lessen the risk posed by some of the chokepoints highlighted in the former President's struggle to overturn the 2020 election. Reducing the leverage of "centralized" aspects of the U.S.'s decentralized system, for

/2020/11/30/trump-renews-ballot-dump-conspiracy-theory-claim-heres-why-its-bogus/?sh= 6c2892bf1dca [https://perma.cc/9CM3-XSDA]; Trump, supra note 1. 
example by clarifying Congress's role under the Electoral Count Act, may also be useful.

Still, the images of county officials painstakingly tallying each individual ballot, with monitors from both parties peering over their shoulders, provide a stark contrast to gun-toting protesters demanding a stop to the count, or storming the U.S. Capitol in a violent rage. They suggest a continuation of American democracy, despite an unprecedented effort to undermine it. 